\title{
Very Fast Growing
}

National Cancer Institute

\section{Source}

National Cancer Institute. Very Fast Growing. NCI Thesaurus. Code C124826.

An indication that something is growing at a very fast rate. 